\title{
Commercial Equity: The Quistclose Trust and Asset Recovery
}

\author{
Sue Tappenden \\ University of Waikato \\ Hamilton, New Zealand \\ E-mail: SUETAPP@waikato.ac.nz
}

\begin{abstract}
This paper examines the impact of equitable principles on the sphere of commercial law. It will make particular reference to the effect of the incursion of equity on ordinary creditors with regard to obtaining priorities in cases of insolvency. It will analyze the Quistclose trust and show how this type of trust may be used to obtain an advantage by those who would otherwise be ordinary creditors. It will refer to the use of equitable tracing to recover assets in a money-laundering scheme The paper will suggest that judicial acceptance of the concept of the remedial constructive trusts has enhanced the development of proprietary restitutionary remedies in commercial transactions where no proprietary remedy would have previously existed.
\end{abstract}

Keywords: Quistclose, Trust, Creditors, Remedies, Commercial, Law, Remedial, Constructive

Steve Hedley once described a school of thought which suggested that such a vague conception as equity, with is 'oddly moralistic concepts' and refusal to 'fit itself into neat categories' deserved to be put out of its misery. He said: 'If some say that equity is dying, then the fact must be admitted - but so is the common law. The great legal innovations today are statutory, not common law; when new law is needed, it is made by the legislature....'(Note 1) He concluded his observations by saying that while the common law is still with us equity is needed, although how long the common law would be with us was anyone's guess.

This way of looking at equity sees it as having a corrective function, interjecting its doctrines in places where the common law is found to be lacking. But although equity may have begun in that way, through ancient Chancellors dispensing equity's justice in the face of a defective common law system, today's equity has taken on a larger role and recently has seemed to be making incursions into a hitherto restricted zone. Equity is being utilized for the imposition of equitable principles in commercial situations and we are witnessing the judicial use of those principles to support decisions where fiduciary relationships are imposed upon people linked by contract, and trust concepts protect funds for the benefit of unsecured lenders in the face of obligations owed by debtors to their ordinary creditors. This paper looks at what is being done in the name of equity by the judiciary to change the nature of relationships in the commercial world and at the protection of the interests of unsecured transferors of property to the detriment of the creditors of insolvent transferees.

There are two avenues I wish to explore through the medium of this paper, which may appear at first sight to be disparate threads of enquiry. Yet I believe, and I hope to show, that the two are linked. I am referring to the increasing use that is being made of the so-called Quistclose trust (Note 2) and the implementation of the proprietary remedy which in New Zealand is known as the remedial constructive trust. I also wish to discuss the differences between making judicial rulings based on principle, or the balance of competing rights, and rulings based on policy considerations. In using these two strategies, the Quistclose trust and the remedial constructive trust, the courts are able to discover proprietary interests in commercial transactions. If I were analysing the decisions in a jurisprudential sense I would call upon Dworkin's theory of judicial interpretation. Dworkin would tell us that the judiciary is either establishing one party's rights to be greater than another's based on principle or else they are making decisions to redistribute property based on some policy consideration. Dworkin would also say that this latter process of grounding decisions in policy lies outside the purview of the judiciary in any case. Either way, what the judges are doing is broadening the application of equity and changing the way property is held in an area of law dominated by statute, somewhat giving the lie to Mr. Hedley's idea that change is the province of parliament through legislation.

Barclays Bank Ltd v Quistclose Investments Ltd(Note 3) (hereafter Quistclose) was based on a line of cases that formed a precedent for the proposal that when property was transferred to a debtor for the repayment of that debt the property should be returned to the transferor if the debt was not repaid. As early as 1806, in the case of Hassall v Smithers(Note 4) money was provided for payment of specific bills. The debtor died intestate without paying the bills and the provider of the money, together with those bill holders, was able to compel the intestate's personal representatives to use the money provided for the specific purpose(Note 5). By the middle of the $19^{\text {th }}$ century a slightly broader had become established. Where money had been lent to a debtor to pay off his pressing creditors and it was made clear that the money could not 
be used for any other purpose, the money lent for that purpose became 'clothed with a specific trust' (Note 6). This was the judgment of Abbott CJ in 1819 in the case of Toovey v Milne. It was decided that, if, before the money was paid to creditors, the debtor became bankrupt, that money had to be repaid to the lender. The trustee in bankruptcy would be bound by an 'implied stipulation' (Note 7) to return it and the money would not become part of the debtor's assets. This reasoning was applied in Edwards $v$ Glyn(Note 8) in 1859 and became a well established principle in cases involving personal bankruptcy. Lindley LJ in Re Rogers (Note 9) went so far as saying:

'I entertain no doubt that [the lender] could have obtained an injunction to restrain the bankrupt from using that money for any purpose except that of paying his pressing creditors.

That being the case the money could not vest in his trustee as part of his assets as the debtor never had the beneficial interest in the money.

It was not until Quistclose in 1970 that the House of Lords applied this line of authorities in the context of corporate insolvency. Now we have a situation where lenders use the Quistclose trust to protect themselves against the risks inherent in their borrowers becoming insolvent and thus absolving themselves from the necessity of taking security for their loans. In examining the concept behind the doctrine, several questions arise as to the nature of the Quistclose trust. It may be a type of proprietary remedy, and if that is the case we will be able to show an express trust to have been created so that the transferee may be said to have never enjoyed the beneficial interest in the transferred property.

It may be a type of purpose trust which for some reason is not declared void for want of certainty of object. Perhaps it is analogous with the doctrine spelt out in Re Denley(Note 10) which was a purpose trust that would have been void for lack of beneficiaries but was saved by being found to be for the benefit of individuals. I will come back to this idea. Another possibility is that the Quistclose is a constructive trust and if it is what sort of constructive trust could perform its functions. Again, I shall return to the idea of a constructive trust being at the heart of the doctrine found in Quistclose.

The case itself is fascinating and it's one I use to stir up enthusiasm for equity and trusts in my classes. I use it as an example of what a trust can accomplish, even when we are not sure if it is in fact a trust. I use it as an example of how the devious and well informed can overcome the ordinary shareholders, workers and ordinary creditors of a firm that continued trading even though its managing director ought to have known it had long since passed the brink of bankruptcy. The man behind the company is also fascinating in the way he was able to get away with so much for so long.

As you will know, the Quistclose case was brought by Barclays Bank who wanted to use money they held in an account for a company called Rolls Razor to offset an unauthorised overdraft amount. In June 41964 Rolls Razor owed Barclays Bank 484,000 pounds whereas its overdraft limit was set at 250,000 pounds. Barclays Bank was actually in the best position of all as it had taken a security against the plant and factory valued at 4 million pounds. In May 1964 the managing Director of the company, John Bloom, persuaded his Board to declare a generous dividend at a time when the company's accounts showed a loss of 179,000 pounds for the first three months of 1964. It has been suggested that even this figure does not represent the true amount of the deficit. A subsidiary electronics firm was close to collapse. The Board was for the most part in a state of denial as far as the financial position of the company was concerned. The paperwork was in a state of chaos but they knew that a cash injection was needed and it was suggested by one director, Jack Jacobs, that unless money was forthcoming the board should recommend liquidation. In order to meet the payment of the dividend Bloom approached Sir Isaac Wolfson, who was referred to mysteriously as $\mathrm{Mr} \mathrm{X}$ in the Court of Appeal judgment of Harman LJ. Sir Isaac Wolfson had a vested interest in keeping Rolls Razor going. The firm was manufacturing and selling washing machines. Wolfson's finance company was providing the Hire Purchase finance which enabled ordinary people to buy the new washing machines which were sold door to door at heavily discounted prices. They were very popular and while people entered hire purchase agreement, Wolfson was making money. The figure suggested was one million pounds which was to come from Wolfson's company, General Guarantee Corporation. However the money was transferred to Quistclose Investments Ltd by Bloom himself. It was a shell company and the source of the money has never been properly documented. Most people believed it was Wolfson, through General Guarantee Corporation, others say it was Barclays Bank, although this was unlikely. Whatever the source Bloom's confidence soared and he was convinced that a financial hurdle had been overcome.

At this point I want to elaborate on something Robert Stevens said, in his chapter entitled 'Rolls Razor Ltd'(Note 11) in 'The Quistclose Trust: Critical Essays' that John Bloom went to the school 'labelled by some sections of the press as the worst school in Britain'. While it is true that the school that now occupies the site of Bloom's old school on the edge of Hackney Downs was closed in 1995, having been shown to be an educational disaster, that school was not the one Bloom attended. John Bloom went to the Grammar School which was originally on the site. It was known locally as The Grocers' School and was in fact inaugurated by the Worshipful Company of Grocers in 1876. Entry was by examination only and only the brightest of students could attend. It was a hugely successful School with an enviable reputation and alumni that includes playwright, Harold Pinter; writer and actor, Steven Berkoff; physicist, Cyril Domb 
and world darts champion Eric Bristow. Sir Michael Caine also attended the school for a while in the 1940s, as did my cousin Professor Gough who is at the University of Cambridge. John Bloom wasn't the wild boy from the East End of London some sources try to portray, instead he was intelligent and had entrepreneurial skills for which, for some time, he was respected.

In July 1964 Quistclose Investments Ltd wrote a cheque in favour of Rolls Razor for nearly 210,000 pounds. When the cheque was sent to Barclays Bank it was accompanied by a note. The instruction to the bank was that the money should be paid into a separate account and held for Rolls Razor for the purpose of paying the declared dividend. It is believed that during the negotiations with Sir Isaac Wolfson a stipulation was raised that the loan was conditional on the dividend being paid. The payment into the Rolls Razor account was sufficient to boost Bloom's confidence that all would be well to the stage where he felt comfortable taking a holiday in Bulgaria where his yacht was moored. Arranging holidays in Bulgaria was another of Bloom's entrepreneurial schemes, called Rolls tours, and it must be admitted that, as terrible as the holidays sounded, with hours of coach travel through communist countries, they were the start of the modern package holiday.

This of course was a terrible mistake. Without their charismatic managing director to guide them, the board accepted the advice of a financial adviser (who had been very well paid in advance for his services) that the company should be immediately wound up voluntarily on the grounds that it was hopelessly insolvent. When Bloom returned from Bulgaria three days later he had no choice but to accept what had been decided in his absence. It was at this point that Barclays informed Rolls Razor that it intended to exercise its power and combine the overdrawn account with the share dividend account and the Quistclose case as we know it began.

I have gone into a lot of background detail to illustrate the point that if indeed a trust was being created by this sequence of events the company which would benefit from the trust is Quistclose Investments Ltd which was a shell company, under the control of John Bloom, who supplied the money that was lent to Rolls Razor. The reason for the elaborate arrangement to ensure the dividend was paid was not altruistic regard for the shareholders, but rather was part of a larger scheme to ensure that financial support was forthcoming from a party who was intimately concerned for the continuation of Rolls Razor to ensure his own profits did not diminish. The immediate effect of the loan was to make the company appear to be solvent, when it clearly was not. All of these factors are inherently repugnant to equity yet none of this was discussed by the House of Lords. Nor was the issue raised as to why the shareholders were no longer represented by the time the case was heard by the Lords.

Unlike the earlier nineteenth century cases the concern was not for the fulfilment of the purpose of the loan but instead the protection of the lender. The House of Lords was persuaded that the financial arrangements surrounding the transfer of the funds clothed the funds in a trust and imposed a fiduciary obligation on the one who held the money (Barclays Bank) to return the funds to the transferor (Quistclose). Usually a trust will be declared with the consent of the parties unless the trust is imposed as the result of circumstances. (Note 12) Although a chose in action can undoubtedly serve as the subject matter of a trust the problem remains as to the identities of the settlor, trustee and beneficiary.

If we say that Quistclose Investments Ltd was the settlor we may say that Rolls Razor acted as trustee and the chose in action was created when Rolls Razor deposited the money into the Barclays account which Rolls had received from Quistclose. However Lord Wilberforce disagrees with this analysis, preferring Barclays Bank in the role of trustee. He asks (Note 13) whether Barclays Bank has notice of the terms upon which the loan was made. This is a difficult point to overcome if we are to accept the arrangement as a trust since one cannot be a trustee of money that is owed to another and in its relationship with Rolls Razor the bank merely holds the money under a contractual duty to the depositor, not as trustee. If on the other hand Rolls Razor is the trustee, we must look for a declaration of trust by Quistclose which showed an intention to vest rights in Rolls Razor as trustee, rather than as outright owner. The only indication we have of any restriction is the note that accompanied the deposit, saying that the fund was to be used for the payment of the dividend. But that note came from Rolls Razor, not Quistclose, although Lord Wilberforce appears to ascribe the same intention to Quistclose Investments Ltd. (Note 14), although the proviso was never declared by that company.

Whoever expressed the intention, and whether or not it can be ascribed to Quistclose Investments Ltd, there still remains the problem that by stipulating where and how the funds should be applied is not the same as creating a trust. There are many examples of cases where a transfer encumbered with a condition for its use was declared not to constitute a trust. (Note 15) The stated purpose can only serve to define the subject matter of the trust or show the motive behind the transfer; it does not of itself create a purpose trust. Even if it was capable of creating a purpose trust there are huge obstacles to overcome to avoid the purpose trust from being declared void for lack of a human beneficiary. This is a topic to which I shall return.

The issue of keeping the transferred funds in a separate account has been identified in some cases as crucial to the finding of a Quistclose trust (Note 16), but Quistclose Investments did not impose any duty of segregation over the money. The bank was advised by Rolls Razor to keep the money in a separate account but this stipulation did not come from Quistclose Investments. One may ask whether the absence of such a stipulation from the lender allowed the 
borrower to take the benefit of the transfer absolutely. A larger issue is that of identifying a beneficiary of any trust that may exist.

Peter Millett wrote about the issue prior to his elevation to the Bench in 'The Quistclose Trust: Who Can Enforce It?' (Note 17) in which he found the result to be 'simple and orthodox'.(Note 18) He saw the Quistclose arrangement as a bare trust accompanied by a mandate to use the money for a specified purpose. When the purpose of the mandate failed (to pay the dividend) the express trust protected the rights of the lender and ensured that the money was returned to him. So for Peter Millett the Quistclose trust is not remedial, there is no need for a resulting trust nor should a constructive trust arise. The Quistclose trust merely gives effect to the wishes of the settlor, Quistclose Investments Ltd. This view has certainly been adopted in New Zealand by the Court of Appeal in General Communications Ltd v Development Finance (Note 19) and in Australia in the High Court: in Australasian Conference Association Ltd v Mainline Constructions Pty Ltd (1978) (Note 20) Gibbs ACJ, with whom the other two members of the majority of the court agreed, said at page 353 that Quistclose:

"is authority for the proposition that where money is advanced by A to B, with the mutual intention that it should not become part of the assets of B, but should be used exclusively for a specific purpose, there will be implied (at least in the absence of an indication of a contrary intention) a stipulation that if the purpose fails the money will be repaid, and the arrangement will give rise to a relationship of a fiduciary character, or trust."

The analysis appears to be very neat, but it is not without some inherent difficulties.

In comparison to General Communications (above) where the money was transferred for the purchase of equipment, Templeton Insurance Ltd v Pennington Solicitors LLP(Note 21) was a case concerning the transfer of funds for the purchase of specific land. When the purchase was not completed Lewison J considered that there was a Quistclose trust but the beneficial ownership was to remain with the transferor. The trust was analysed as a resulting trust accompanied by a power to use the money for a purpose. Lewison J did not consider it necessary for there to be crystal clarity as to the restricted purpose intended by the settlor, as long as it could be shown that the money was not intended to be at the free disposal of the recipient.

There is some confusion as to whether it is crucial that the settlor attaches clear stipulations to the funds that are being transferred. In EVTR(Note 22) Dillon LJ accepted 'that nobody gave a conscious thought' to the proposition that the purpose for which the money was being advanced (to purchase equipment) might not be fulfilled. Still, despite this, Dillon LJ found there to be a proprietary interest in the lender's favour. My question would be: how could any settlor intend to create a trust if he gave no thought to it? There are other, wider issues. One such is whether the obligation borne by the borrower in that case should be any more than a personal obligation to return the money. Furthermore where did the proprietary interest originate? But for me the biggest consideration is how a court could infer an intention to create a trust when the lenders themselves did not recognise the importance of reserving a proprietary right over the money to protect them from the possibility that the borrower might become bankrupt, which in turn would expose the lender to risks.

For Dillon LJ these considerations constituted no barriers to his findings. He said,

'A constructive trust most normally arises by implication of law when circumstances happen to which the parties had not addressed their minds.'

This leaves me to wonder whether Peter Millett's earlier analysis was abandoned by EVTR since Millett's theory was concerned with express trusts, not resulting or constructive trusts. However the two positions are linked since it is probable that a resulting trust will arise when an express trust fails. However I come back to my main objection to the analysis of the position in EVTR in that it is absurd to talk of inferring an express trust from a loan arrangement when the lender had not given any consideration at all to the advantages that an express trust would bring. In the express trust analysis the lender seems to somehow mysteriously acquire all the powers of a beneficiary under an ordinary express trust. If this were the case the lender would have acquired the power to revoke the loan and bring it to an end whether or not there was any default under the ordinary common law powers of a beneficiary who is sui juris and in control of the whole beneficial interest. This power would go far beyond the power to restrain the borrower from making unauthorised use of the money.

It would appear to make more sense if the analysis of Dillon LJ were viewed as the creation of a remedial constructive trust. This proprietary remedy has become increasingly popular in New Zealand. In New Zealand we have embraced the notion of fusion between law and equity more readily than in England or Australia and the courts are more likely to be ready to find a remedial constructive trust in order to give a remedy when principles of justice and good conscience require it. The remedial constructive trust is a very attractive device. Lord Browne-Wilkinson has hinted that the way forward for English law may involve the recognition of remedial constructive trusts and in the Westdeutsche case(Note 23) he went so far as to explain the difference between the institutional and remedial constructive trusts. The main difference is that in the circumstances of the institutional constructive trust the proprietary interest exists before the 
plaintiff comes to court and the court just gives effect to a trust which arose out of specific circumstances. However, the remedial constructive trust gives rise to a previously non-existent proprietary interest at the discretion of the court to reverse some injustice.

As early as 1949 Sir Alfred Denning (as he then was) gave the first Hamlyn Lecture in which he identified the challenge facing the court as being to develop 'new and up-to-date machinery'. In his judgment of the previous year, Nelson $v$ Larholt (Note 24) he said,

"It is no longer appropriate, however, to draw a distinction between law and equity .... Remedies now depend on the substance of the right, not on whether they can be fitted into a particular framework. The right here is not peculiar to equity or contract or tort, but falls naturally within the important category of cases where the Court orders restitution, if the justice of the case so requires"(Note 25)

In 1972 during Lord Denning's term as Master of the Rolls, in his judgment in Hussey v Palmer(Note26) Lord Denning made the remark that the resulting trust and the constructive trust 'run together'. 'By whatever name it is described,' he said, 'it is a trust imposed by law whenever justice or good conscience require it.' He went on to say, 'It is a liberal process, founded upon large principles of equity, to be applied in cases where the defendant cannot conscientiously keep the property for himself alone'.

In 1990 Aquaculture Corp v NZ Green Mussel Co Ltd (Note 27) was decided by the New Zealand Court of Appeal and in this case the court formulated the 'basket of remedies' approach. The aim was to make as full a range of remedies available as possible so that a remedy might be chosen because it is appropriate without having to consider whether its origin was in common law, equity or statute. This decision signalled the New Zealand Court of Appeal's willingness to focus on the outcome of a particular case rather than the theoretical foundations of the remedy so the remedy could be chosen on the basis that it provides the best outcome not because the antecedents of the remedy arose out of equity or the common law or even indeed from statute.

Parties who considered themselves to be in a contractual, non-fiduciary, relationship may find they are bound to undertake all the rigorous duties that are demanded of a trustee and money they regarded as profit becomes the subject matter of a hitherto unsuspected trust. For example in the case of Dickie v Torbay Pharmacy (1986) (Note 28) in 1995, a fiduciary relationship was found to exist between potential joint venturers. When a breach of the fiduciary duty occasioned the finding of a proprietary remedy, the remedial constructive trust was applied. Hammond J considered the nature of a constructive trust and concluded that 'functionally constructive trusts can, and do, serve a variety of purposes'. He came to the conclusion that abstract theory should give way to the circumstances of a given case, the nature of the wrong and whether proprietary relief is appropriate. Equity affords the judge the opportunity to protect property by way of a constructive trust and force the disgorgement of money to the party who has been wrongly denied it. In New Zealand it makes no difference whether the parties were engaged in a commercial enterprise which would normally have been governed by a contractual relationship, the equitable remedy is available.

So if we were to apply the remedial constructive trust to the Quistclose trust it would work in the following way. The money advanced by Quistclose Investments Ltd would have been impressed by a trust by way of the intended use to which the funds were to be put. If the intended purpose was not and could not be fulfilled it would be unconscionable for Rolls Razor to keep the funds (albeit that they were in the hands of Barclays Bank) and it could even be seen as an unjust enrichment on the part of Rolls Razor if the funds were not returned. One huge disadvantage of this analysis is the fact that by appealing to a court in equity all the maxims of equity come into play. The remedy is discretionary and depends upon, amongst other things, the equitable nature of the lender's claim. If the lender has a vested interest in deceiving the public as to the true financial position of the borrower and if the borrower were to be shown as trading while insolvent, it is very unlikely that equity will look very kindly on either the lender or the borrower to the extent of applying an equitable remedy.

Perhaps there is another possible analysis of the case. Perhaps the Quistclose arrangement might be seen as being a particular kind of express trust which falls outside the requirement to show certainty of object, that is to say to show that there is a human beneficiary rather than just a purpose to which the money should be used. In Quistclose the emphasis is placed on the purpose which has been impressed upon the transferred money and I think it is easy to overlook the problem of discovering who the beneficiaries of the trust are. If the shareholders are identified as the beneficiaries of an express trust then the answer is clear - simply find the company's list of shareholders and distribute the money. However that is said to be impossible since the company no longer exists. A trust needs beneficiaries who can enforce the trust as against the trustees. If the shareholders are not the beneficiaries then it is a purpose trust and, not being a charitable trust, it should be declared void. The whole idea of a resulting trust coming into play when an express trust fails will only work if there is an express trust to begin with.

There was an attempt in Giles v Westminster Savings Credit Union (Note 29) in the British Columbia Supreme Court where Sigurdson $\mathrm{J}$ tried to clothe a Quistclose - like arrangement with the three certainties required for the 
establishment of an express trust. This attempt was doomed to failure as an express trust requires certainty of intention and it was impossible to show a clear intention by the parties that the beneficial interest was to remain in the lender.

Another approach to the issue of where the beneficial interest lies in the Quistclose trust comes from an Australian case, Australian Elizabethan Theatre Trust(Note 30) in which Gummow J said that, while the borrowers remain solvent, they hold the interest for the benefit of the creditors. Once the borrowers are insolvent the property returns to the lender by way of a gift over. This analysis is hard to accept because if the creditors have the beneficial interest in the property it is difficult to see how this is terminated on the insolvency of the borrowers.

If there is no certainty of object or certainty of beneficiary there can be no trust unless we can bring the Quistclose trust in line with a case from 1969 called Re Denley's Trust Deed(Note 31) (hereafter Denley). The settlor in Denley wanted to provide sports and recreation facilities for his employees and their families and friends. He transferred funds to trustees with the instructions as to their duties. The trust was challenged as being a non-charitable purpose trust and therefore void for not having human beneficiaries. Goff J overcame the problem by taking the approach that the Denley trust lay outside the mischief of the beneficiary rule. In other words this was an exception to which the beneficiary rule need not be applied. In any case the court found that there was in fact a trust for persons, simply expressed as a trust for a purpose. If we could apply that reasoning to Quistclose we may be able to overcome some of the problems inherent in finding a valid trust if we simply say the case falls outside the mischief envisaged by the beneficiary rule requirements. This was the conclusion reached by Ho and Smart. (Note 32)

In this way Quistclose would simply step into the anomalous class of extraordinary trusts that are not void for lack of a beneficiary. Trusts for the upkeep of tombs and graveyards fall into this class as do trusts for the maintenance of packs of hunting hounds and stables of racehorses. If the purpose fails then a resulting trust is imposed and the subject matter of the trust returns to the transferor. In Re Westar Mining Ltd (Note 33) it was assumed by the court that the Quistclose trust is a purpose trust, in fact the two were treated as being synonymous. Mutual intention to create a trust was found to exist so that money in a bank account was found to be impressed with the trust and not available to the mine's creditors. The issue of lack of certainty of beneficiaries was not discussed. It was assumed that this type of trust was outside the mischief for which the rule relating to beneficiaries was created.

However it is a rather large step to take from the accepted exceptions to the beneficiary principle which enable the courts to allow trusts for tombs or beagles, to the Quistclose trust which allows funds in a bankrupt's bank account to be shielded from the claims of creditors. Even if we proceed via Denley it seems to be stretching the bounds of reasoning by analogy. In Denley there were humans who would benefit from the trust, in Quistclose the shareholders cannot benefit from a company that is no longer trading. In Denley there is no doubt about who are the trustees and there is no doubt about the settlor's intentions. In Quistclose the restrictions on the use of the money did not come from the settlor but from another party. It cannot be said that the settlor made its intentions clear. There is also doubt about who the court thought was the trustee, Rolls Razor or Barclays Bank. My final objection to analysing Quistclose as a Denley type trust is that in Quistclose the trust concept is being used to disgorge money in a kind of action for restitution.

If we reject the purpose trust analysis then we may favour the interpretation of Potter LJ in Twinsectra $v$ Yardley (Note 34) where he described the arrangement as an 'express pupose trust'. Adopting an analysis of Peter Gibson J in Carreras Rothmans Ltd v Freeman Matthews Treasure Ltd (Note 35) Potter LJ said, 'as long as the primary purpose trust continues, the beneficial interest in the monies lent is "in suspense" until applied for that purpose.' (Note 36) There are several examples of cases where that approach seems to have been applied. From the Alberta Court of Queen's Bench in 2003 comes the case of Reed v Toronto-Dominion Bank.(Note 37) Master Funduk was trying to resolve the issue of what happened to $\$ 75,000$ that Reed gave to purchase certain shares. In answering a question as to whether the money was the subject matter of a trust, Master Funduk responded'

'If money is given to be used only for a specific purpose it is today called a Quistclose trust.' (Note 38)

And having thus established the trust he went on to make two of the defendants liable in knowing assistance in the breach of the trust because the shares were not bought with the trust money. Master Funduk had no difficulty with the notion that the beneficial interest could be held in suspense in this way and if not applied for the specified purpose would crystallise in favour of the plaintiff.

In another Canadian case, this time from the British Columbia Supreme Court in 2004 Mr Zhou met Ms Wang in a massage parlour and was so taken with her that he gave her some money to pay off her husband. She said she was in an arranged marriage for the purpose of acquiring Canadian residence and was indebted to her husband. This money was said by the court to be under a trust following Quistclose, as the money was advanced for a special purpose and thus became impressed with a trust for the purpose. (Note 39) Ms Wang did not enjoy the beneficial ownership of the money and when the money was not used for the purpose of paying off her husband the beneficial interest that had been in suspense vested once more in Mr Zhou. 
It would appear that, whatever its theoretical basis, the Quistclose trust is being applied on the broad jurisdiction of equity in many common law countries. The questions with regard to the difficulty in adhering to the beneficiary principle seem to have been forgotten.

During later years it would appear that the original reasoning in Quistclose has been expanded. It is not clear exactly when this happened but certainly in 1988 there is evidence that the Quistclose principle remained limited to its original parameters. For example in Re Miles; Ex parte National Australia Bank Ltd v Official Receiver in Bankruptcy which was heard in the Federal Court of Australia (Note 40) it was held that the principle in Quistclose is limited to situations where money is paid to the payee for the purpose of discharging debts and that purpose fails.

This original version of the principle expounded in Quistclose was correctly supported by precedent from the nineteenth century. However by 2002, in the words of Lord Millett in Twinsectra. (Note 41)

'Money advanced by way of a loan normally becomes the property of the borrower..........But it is well established that a loan to a borrower for a specific purpose gives rise to fiduciary obligations on the part of the borrower which a court of equity will enforce. In the earlier cases the purpose was to enable the borrower to pay his creditors, or some of them, but the principle is not limited to such cases'.

The expanded version is now being relied upon to enable transferred property to be returned to the transferor in many varied situations without the benefit of a sound basis of precedent or conceptual certainty. The situations vary from case to case but all of the instances are based on the words of Lord Millett cited above. For example there was the case of a Greek wife who managed to reclaim her lottery winnings of 2 billion drachmas after her husband had taken it out of their joint account to set up a foreign exchange margin account in the UK on the basis that when she placed the money in the account it was impressed with a Quistclose trust. Accordingly the proceeds could be traced into the new, US dollar bank account and members of the bank's staff were found to be liable for knowingly assisting the husband in breach of the trust. (Note 42)

Whereas in Miles (above) the court found that there was no trust over a bankrupt's funds, in 2002,Kennedy v Bohnet (Note 43) when in a bankrupt held a deposit in his account for the purchase of a golf course, the court found there to be 'an express Quistclose trust... The $\$ 400,000$ was to be used for a specific purpose only and if it was not used for that purpose it was to be returned.' The Quistclose trust has been used as the equitable interest forming the basis upon which to lodge a caveat (Note 44) but for the most part the greatest use has been in the area of insolvency. For example the case of Glen Eight Pty v Home Building Pty Ltd (Note 45) concerned a transfer of funds into a mixed bank account. The court was able to discern that the funds paid in by the defendant were impressed with the purpose of paying the contractors and that was sufficient to merit the imposition of the Quistclose trust.

In the same court, in the same year the Supreme Court of New South Wales appears to has come to its own definition of the Quistclose trust in Frontier Touring Co Pty Ltd v Rodgers (as liquidator of Kidz.net Services Pty Ltd (in liq)) (Note 46) where it was stated:

'It is unconscionable for a man to obtain money on terms as to its application and then disregard the terms on which he received it. Such conduct goes beyond a mere breach of contract....In the present case, as I have already said, the relationship of the plaintiff and Kidz.net was not that of lender and borrower. In conceptual terms, the plaintiff may be regarded as having settled funds on Kidz.net so that Kidz.net might apply them in the manner stated. This, to my mind, reinforces the applicability of the resulting trust principles referred to in Twinsectra. The plaintiff paid money to Kidz.net (and Kidz.net accepted it from the plaintiff) for a stated purpose, so that Kidz.net came to hold the money upon trust to apply it for that purpose and, in default, to hold it for the plaintiff. Clearly implicit in the trust was a duty on the part of Kidz.net not to apply the money otherwise than in fulfilment of the stated purpose. That duty was accordingly a fiduciary duty.'

I think this is a most comprehensive analysis with, I believe, all the elements from the different ways of explaining the Quistclose trust. We have the unconscionablity of the remedial constructive trust, the plaintiff as settlor of funds, and a resulting trust. We have the element of the purpose trust with a trust crystalising in the event of default and a fiduciary duty not to misapply the funds. This analysis adheres most closely with the fundamental principles of the trust, created by the Court of Equity to work on the conscience of the transferee and in my view is the best way of looking at the Quistclose trust.

Flexibility has always been prized by Equity but the note of caution is often sounded that too much flexibility leads to uncertainty and too much discretion is judicial anarchy. However, if a wrong is identified where no remedy as yet would give relief it seems that it is the very essence of equity that all available sources should be used to find a remedy.

Even in criminal cases, for example involving money laundering, principles of equity are being called upon to recover funds. For example PBM (HK) Ltd v Tang \& Ors (Note 47) was a case an employee who utilised accounts of his employer's clients to engage in money laundering practices. The profits from his illegal activities were passed to his girl friend, with whom he was living, and placed in her bank account. Although she did not take part in the money 
laundering it was held by the court that she 'must have known' that her boyfriend could not have come by such large amounts of money legally. Plus she knew that her boyfriend had a slavish lifestyle which he could not have maintained on his salary. These facts, said the court, were enough to trigger the equitable principle of tracing. She was not prosecuted, and her own dishonesty was not proven, just that of her boyfriend. The court assumed her knowledge of the dishonest activities of Tang and was prepared to use equitable principles to disgorge the money from her account.

Equity is commonly used in this pragmatic way to provide the courts with a remedy that perhaps otherwise would not be available. So it is with the Quistclose trust. While the roots of the conceptual analysis of Quistclose remain open to debate, in many courts the practical ramifications of that conceptual uncertainty are being eroded, particularly in commercial cases. Perhaps it is sometimes felt necessary to impart some sense of morality into cases involving businessmen or sometimes the reason is pragmatic, simply to find the most suitable remedy for the situation.

\section{References and Notes}

Ex parte Holland and Hannen. (1891). 8 Morr 243 at 248.

A-G for Hong Kong v Reid. (1994). 1 AC 324 is a good example of a constructive trust that has been imposed as a result of circumstances.

Reinterpreting the Quistclose Trust; a Critique of Chambers' Analysis Oxford Journal of Legal Studies. (2001). 21(2) 267

\section{Notes}

Note 1. S Hedley, 'Rival Taxonomies Within Obligations: Is There a Problem?' in S Degeling \& J Edelman (Eds) Equity in Commercial Law (Lawbook Co., Sydney, 2005)

Note 2.From Barclays Bank Ltd v Quistclose Investments Ltd [1970] AC 567

Note 3.Above $\mathrm{n} 2$

Note 4. (1806) 12 Ves 119

Note 5.In 1884 North J referred to these principles as 'very well known law'. He said, in Gibert v Gonard, 'It is very well known law that is one person makes a payment to another for a certain purpose, he must apply it to the purpose for which it was given.'

Note 6.Toovey v Milne (1819) 2 B \& Ald 683 at 683.

Note 7. ibid

Note 8. (1859) 2 E \& E 29

Note 9.Ex parte Holland and Hannen (1891) 8 Morr 243 at 248

Note 10. Re Denley's Trust Deed [1969] 1 Ch 373

Note 11.In W Swadling (Ed) The Quistclose Trust: Critical Essays, (Hart Publishing, Oxford, 2004) at 1.

Note 12. A-G for Hong Kong v Reid [1994] 1 AC 324 is a good example of a constructive trust that has been imposed as a result of circumstances.

Note 13. [1970] AC 567, 579, 582.

Note 14. Ibid at 579-580.

Note 15.For example: Re Lipinski [1976] Ch 235, Re Osoba [1979 1 WLR 247.

Note 16. See Re Farepack Food \& Gifts Ltd (In administration) [2006] EWHC 3272 (Ch) (Companies Court)

Note 17. (1985) 101 LQR 269

Note 18. Ibid at 284

Note 19. [1990] 3 NXLR 406

Note 20.141 CLR 335

Note 21. [2006] EWHC 685 (Ch)

Note 22. [1987] BCLC 646

Note 23. Westdeutsche Landesbank Girozontrale v Islington Borough Council [1996] AC 669.

The former arises as at the date of the circumstances that give rise to it. The court merely acknowledges that the constructive trust has come into existence. On the other hand the latter is a judicial remedy which gives rise to an equitable obligation. It is at the discretion of the court and if the remedial constructive trust acts to the prejudice of third parties, this also is at the discretion of the courts. 
Note 24. [1948] 1 KB 339.

Note 25. Ibid at 343 .

Note 26.1972] 3 All ER 744

Note 27. [1990] 3 NZLR 299

Note 28. [1995] 3 NZLR 429

Note 29. [2006] ACWSJ Lexis 662

Note 30. (1981) 102 ALR 681 (Fed Ct).

Note 31. Above n. 10.

Note 32. Reinterpreting the Quistclose Trust; a Critique of Chambers' Analysis Oxford Journal of Legal Studies (2001) 21(2) 267

Note 33. [2003] BCCA 11

Note 34. [1999] Lloyds Banking Rep 438

Note 35. [1985] Ch 207

Note 36. [1999] Lloyds Banking Rep 438, 456.

Note 37. [2003] A.J. No. 348

Note 38. Ibid para 15

Note 39. Zhou v Wang [2004] ACWSJ Lexis 5773 at para 113

Note 40. (1988) 85 ALR 216

Note 41. Twinsectra Ltd v Yardley [2002] 2 All ER 377

Note 42. Papamichael v National Westminster Bank Plc 2003] 1 Lloyd's Rep 341

Note 43. Kennedy v. Bohnet [2002] ACWSJ LEXIS 2263

Note 44. Hepler v Rosenblum [2005] NSWSC 179

Note 45. [2005] NSWSC 309

Note 46. [2005] NSWSC 668

Note 47. [2002] HCA 12138/1997 (High Court) 